\title{
Global Citizenship Education and Its Implications for Curriculum Goals at the Age of Globalization
}

\author{
Shahla Zahabioun ${ }^{1}$, Alireza Yousefy ${ }^{2}$, Mohammad H Yarmohammadian ${ }^{3} \&$ Narges Keshtiaray $^{4}$ \\ ${ }^{1}$ Ph.D. student, Department of Educational Science, Khorasgan (Isfahan) branch, Islamic Azad University, \\ Isfahan, Iran \\ ${ }^{2}$ Associate professor, Medical Educational Research Center, Isfahan University of Medical Science, Isfahan, \\ Iran \\ ${ }^{3}$ Associate professor, Health Management and Economic Research Center, Isfahan University of Medical \\ Science, Isfahan, Iran \\ ${ }^{4}$ Assistant Professor, Department of Educational science, Khorasgan (Isfahanz) Branch Islamic Azad University, \\ Isfahan, Iran \\ Correspondence: Shahla Zahabioun, Ph.D. student, Department of Educational Science, Khorasgan (Isfahan) \\ branch, Islamic Azad University, Isfahan, Iran. E-mail: Shahla_zahabioun@yahoo.com
}

Received: September 23, 2012 Accepted: Ocotber 19, 2012 Online Published: December 11, 2012

doi:10.5539/ies.v6n1p195 URL: http://dx.doi.org/10.5539/ies.v6n1p195

\begin{abstract}
As the inevitable process of the $21^{\text {st }}$ century, globalization has affected and altered all aspects of human life including education. Therefore, one of the main tasks of any education system is to identify the features and impacts of such process. Thus, the present study was conducted aiming to discuss and examine global citizenship education and its implications for curriculum goals. This study is firstly defining global citizenship education concept as well as its significance and necessity and then it is going to explain global citizenship education concept and its purposes and implications for curriculum goals. This is an analytical research. The results indicate that global citizen holds peculiar features and requires special education in global aspects. Accordingly, the citizenship education compatible with global standards requires an overview of curriculum goals as one of the most important components of education system.
\end{abstract}

Keywords: information technology, global citizenship, global citizenship education, globalization, curriculum

\section{Introduction}

\subsection{Introduce the Problem}

Citizenship has been affected during its vicissitudinous history by different factors and has undergone many changes and upheavals and it has been altered from citizenship as city-state in ancient Greek era and nation-state during age of enlightenment and renaissance to a transnational and global concept. Thus, an interpretation of citizenship as joining a community and a special political realm which requires right and duties in a limited and mutual relationship with the government does not meet the current requirements of international community. Hence, a large section of literature on citizenship studies has been allocated to global citizenship issue.

Brigham identifies global citizenship as an "approach to understand, see and act". He states: global citizenship is A way of understanding - how the world works, links between our own lives and those of people throughout the world.

A way of seeing-social justice and equity, other people's reality, diversity, inter connectedness, and the way that people can make a difference.

A way of acting - exercising political rights, critical thinking, and challenging injustice $(2011,16)$.

Dower discusses how an interest in the idea of global citizenship has developed in the last thirty years because of four main factors, namely:

1) The increasing pressure of global problems requiring common solutions.

2) The general phenomenon of globalization. 
3) Revived interest in the idea of citizenship itself.

4) A revived interest in the perennial approach of cosmopolitanism, often called nowadays the "global ethnic" (quoted by Chen, 2006).

Global citizenship meaningfully address questions of identity, religion, spirituality, ethnicity, culture, politics, economics, society and foreign relations in the twenty-first century (Dower and Williams quoted by Stewart, 2008, p: 6-7). In the other words, components such as identity, dependency, values, morality, culture, ethnicity and religion as well as concepts including rights, responsibility and contributions are challenged in their traditional meaning and are taken into consideration from a global perspective. This issue is resulted from extensive and unpredictable changes in the economic, political, social, scientific and technological aspects of global procedures which has generated strong motivation and tendency for fundamental and irreversible changes in the values, ethics and norms on one hand, and has confronted today's citizen with many challenges. Hence, the curriculum as a dynamic process must continually revise the goals. They should be organized so that they can come to an answer for the fluidity of the citizenship concept.

\subsection{Importance of the Problem}

We live in an increasingly interdependent world, where the actions of ordinary citizens are likely to have an impact on others' lives across the globe. In turn, our lives, our jobs, the food we eat and the development of our communities are being influenced by global developments. In addition the challenges of this topics including pluralism, sustainable development and environmental issues, human rights, conflicts at the international level, subject of values, moral crises and the health of human beings and other creatures involve the citizen of 21 st century in a completely new situation. In other word an evolving and contested concept of citizenship raises important questions about how schooling should respond to new demands. So today's citizen as a member of the international community requires to receive special education for living at the current age and confronting with the challenges ahead. Based on this issues, global imperative in education can be defined by a growing call for the inclusion of a sense of global mindedness that encourages students to develop a consciousness of global connectivity and responsibility(Sullivan and Pashb, 2008, p: 17), and our goal must be to educate global citizens who see themselves not simply as citizens of a local region, but also a human beings bound to all other human beings by ties of concern and understanding "(Piper, quoted by Jefferess, 2008: 29). So, today, educating for global citizenship has increasingly become a shared goal of educators and educational institutions interested in expanding their own and their students' understanding of what it means to claim or to have citizenship in the twenty-first century.

Although the image of education is different in various societies due to being affected by underlying factors including historical traditions, geographical position, social and political structure, economic systems and global trends (Ker 1999), their common point in massive image of education is to educate a good citizen. Oxfam believes that Education is a powerful tool for changing the world because tomorrow's adults are the children and young people we are educating today(2006, p:1). Therefore, Citizenship education should help students to develop thoughtful and clarified identifications with their cultural communities and their nation-states. It also should help them to develop clarified global identifications and deep understandings of their roles in the world community(.Banks,2004,p:1)This means that one of the chief concerns of governments is to educate citizenship good enough in global aspects. Based on this, it is strongly felt that it is necessary to offer a new definition of citizenship, revision of its goals and the requirement of global citizenship education, thus, this study is seeking specifically the following goals:

Explaining global citizenship concept

Explaining global citizenship education concept

Global citizenship implications for curriculum goals

\section{Method}

This study is analytical research in which some investigations conducted on the citizenship and citizenship education as well as global citizenship and global citizenship education in the curriculum were identified through library studies and reviewing books, journal articles, Electronic resources at different data base and Among the most important resources under this study, we may suggest to the studies of international association of educational achievement evaluation, the studies of UK citizenship foundation, the studies of citizenship curriculum in England and Australia, ten-year consecutive studies of Kerr et al (2001-2010), the reports of the investigations carried out in the field of citizenship in Latin America, international journal learning citizenship belonged to the Institute of Training and Development of UK schools, Journal of citizenship studies in England 
and Wales as well as the researches on the curriculum in northern Ireland, Ontario Canada and Oxfam Curriculum. To analyze the findings, an interpretive descriptive method was used. In this study, the researchers reviewed and assessed around global citizenship and its related concepts. In next, the research questions wrote and analyzed concisely. Ultimately, Global citizenship education factors in curriculum were explained.

\section{Theoretical Framework of the Study}

\subsection{Historical Trend and Conceptualizing Global Citizenship}

Conceptualizing global citizenship is controversial, highly debatable and extremely complex and is a term which can be applied to local, national and international realities. In addition although it is found as much in the literature related to citizenship that there is no consensus on the meaning of global citizenship. Global citizenship would seem to provide the conceptual framework for transcending the nation or the barriers of ethnic, religious, or racial difference to include all within a global community (Jefferes, 2008, p: 29-30). Within the Western perspective, notions of citizenship beyond the state have existed for two thousand years and have reflected the assumptions, experiences, concerns, and the diverse political and socio-cultural contexts of the time periods in which they were constructed. During the period of the Roman Empire, the Stoic tradition of "world citizenship", for example, encouraged citizens to work for the "common good" and emphasized the "universal law of nature. During the Enlightenment, Immanuel Kant (1983) introduced the term "cosmopolitan citizen", through his reflections on an interconnected world community (Evans et al, 2009, p: 18).

Throughout the twentieth century the figure of citizenship that has been dominant since the eighteenth and nineteenth centuries has begun to change(Isin, 2009; P: 367). We have witnessed the emergence of new rights including ecological, sexual and indigenous rights throughout the 20th century" (Isin, 2009, 367).

Today in $21^{\text {st }}$ century, growing development and expansion of information and communications technologies have made the people around the world much closer and linked together and converted them into global citizens by eliminating physical boundaries and creating virtual spaces on the one hand, and they have caused transformation of global trends and provoked globalization phenomenon in its economic, political and social aspects.

Then, accordingly they have confronted all aspects of human life with many challenges.

Some of these challenges has Described by Kerr (1999):

- a growing recognition of the rights of indigenous peoples and minorities

- the collapse of political structures and the birth of new ones

- the changing role of women in society

- the impact of the global economy and changing patterns of work

- the effect of a revolution in information and communications technologies

- an increasing global population

The other challenges of the current age on the way of the global citizen are the moral crises (Grodzinsky, 1999; p: 9), immigration phenomenon (Oenen, 2010; p: 301), formation of multiple dependencies and identities at local, national and international levels (Doerinng, 2008; p: 4), formation and development of groups and movements against gender discrimination (Simon, 2006; p: 38) and massive destruction of environment (Hartley, 2001; p: 3).

Muetzelfeldt and Smith(2002) have showed the historical trend of citizenship in a as follows in (table 1).

The fluidity of citizenship indicates that the conceptualizing global citizenship as referring to membership in the great international community is beyond the membership in the local and national community and it is an emergence of a new definition of rights, responsibilities, identity and sense of social belonging as the most important components related to citizenship based on a global perspective.

Global citizenship is a way of the thinking and behaving. It is an outlook life, a belief that we can make difference and make the world better place (Dragon Foundation, 2012). Global citizenship empowers individual human beings to participate in decisions concerning their lives, including the political, economic, social, cultural and environmental conditions in which they live. It is expressed through engagement in the various communities of which the individual is a part, at the local, national and global level. It includes the right to challenge authority and existing power structures, to think, argue and act with the intent of changing the world(keeping and Shapiro,2008). So "'If young people are to make informed and ethical choices about their futures and how they live their lives now they need to be aware of the global influences that shape these choices. Young people need 
to be able to make sense of their place in a complex world and move towards shaping that world for the better"(Development Education Association United Kingdom, 2002, quoted by Bliss, 2005, p:1 )

Scholars characterize global citizenship by rights, responsibilities, morals, virtues, ethics and competencies transposed from a local, regional and national reality onto the international stage. These characteristics are universal and transcend territories, boundaries, ethnicities, religions and cultures. In a sense, global citizenship is a means of creating an inclusive world whereby we, as global citizens, make choices in the political, economic and social spheres that take into account broader global realities (Stewart, 2008; p: 8).

- The essential elements of global citizenship are:

- The wisdom to perceive the interconnectedness of all life and living.

- The courage not to fear or deny difference; but to respect and strive to understand people of different cultures and to grow from encounter with them.

- The compassion to maintain an imaginative empathy that reaches beyond one's immediate surroundings and extends to those suffering in distant places (keeping and Shapiro, 2008).

Accordingly the global citizenship requires the presence of citizens with a global mind and necessary capability to tackle the challenges existing at the current age. So global citizen is a member of a wider community consisting of all humanity that transposes your own sense of identity, loyalty and commitment beyond the nation-state. Sears and Hughes stated that "Today's citizen is increasingly a world citizen"(1996; p: 133), and as a member of the great international community has to acquire knowledge, attitude, values and skills, in order to obtain the characteristics required to deal with the challenges ahead and to comply with the ever-increasing changes of the current age for the purpose to achieve a good and healthy life for themselves and others, which are not obtained but through education. Global citizens or "globally minded citizens view the world and its inhabitants as interdependent and work to develop the capacity to act to advance both their own enlightened self-interest and the interest of people elsewhere in the world by understanding the interconnection of all living things(Hanson, 2010, p: 76, Stevensand Campbell, 2006).

The global citizen as one who is willing to think beyond boundaries of place, identity and category, and recognize all human beings as their equals while respecting humanity's inherent diversity (Jefferess, 2008, p: 29-30). So equality among citizens can be considered as one of the goals of global citizenship (jarrar, 2012, p: 1923).

Based on these issues, citizens in the twenty-first century must be prepared to deal with rapid change, complex local, national, and global issues, cultural and religious conflicts, and the increasing interdependence of nations in a global economy. Becoming a global citizen involves a serious intellectual and moral examination of the most crucial issues facing our world (Watt et al., 2000, quoted by Schweisfurth, 2006, Mayo et al, 2009).Therefore to be a global citizen is to adopt a global perspective that allows one to see the experience of the local community as interconnected with the experiences of others around the world. In general, a global citizen is any person working on the basis that our destiny as human beings is one, and we are all threatened by the negative forces that may destroy the world unless we address them all united as one hand,mind and heart (Jarrar, 2012, p: 1923).

Oxfam sees the Global Citizen as someone who:

- is aware of the wider world and has a sense of their own role as a world citizen

- $\quad$ respects and values diversity

- has an understanding of how the world works

- $\quad$ is outraged by social injustice

- participates in the community at a range of levels, from the local to the global

- is willing to act to make the world a more equitable and sustainable place

- takes responsibility for their actions(Oxfam, 2006; p: 1).

I believe that Global citizenship is not merely a legal concept, but it is strongly moral, since all things in today's world are dependent to each other. Thus, understanding the dependence of the world and mankind on each other, all issues should be taken into consideration from their global aspect. Undoubted, the world [should] is a moral concept. In other words, global citizenship has a inextricably linked and interconnected to the ethics and since there is always a concern on whether human moral legacy at the age of information will be preserved in the museums as a valuable artifact or not, so it seems that another prerequisite to realize the citizenship education is 
to formulate some principles based on a normative system in order to deal with the challenges and consequences resulted by using information and communications technologies. Noddings states that "Our technological capacity has run far beyond our moral competence to manage it, we dream of peace in a world perpetually on the edge of war. One response to this concern is the promotion of global citizenship (2005, p: 1).

\subsection{Global Citizenship Education}

Banks(2003) stated that, Citizenship education has traditionally had a national character and as he puts it: Citizenship education must be transformed in the 21 st century, because the students will be different than their past (quoted by Munck, 2010, p:33). Based on International Association for the Evaluation of Educational Achievement's report many societies are now worried about how the youth and adolescents should be trained for civil life and how they should be provided to be able to participate in the social responsibilities as a global citizen at the age of globalization (Purta and et al, 1999: $\mathrm{p} 12$ ).

Students as a global citizens must develop a deep understanding of the need to take action and make decisions to help solve the world's difficult problems. They need to participate in ways that will enhance democracy and promote equality and social justice in their cultural communities, nations, and regions, and in the world. So Citizenship education should help students to realize that "no local loyalty can ever justify forgetting that each human being has responsibilities to every other"(Banks, 2008, p:131-134). Students need to receive education in ethics, social behavior, and skills to be able to have a real understanding of the world and be active and independent in social life (Navehebrahim and Masoudi, 2011, p: 275). As citizens of the global community, Students need to develop the knowledge, attitudes, and skills that will enable them to function in a global society.

Making desirable changes in the mode of insight, attitude and behavior of the individuals and acquiring necessary capabilities and skills for them on the one hand and maintaining and continuing social life, economic development and political stability of the communities on the other hand, both require the presence of active, effective and skillful citizens. So the global citizenship education as an underlying issue has drawn a particular attention to itself in different areas. In the field of research, many fundamental studies have been conducted on the citizenship education in the form of associations, conferences, researches and compilations. This focus indicates the key role of education in educating global citizen as a key for happiness and prosperity of societies and empowerment of the students to achieve a favorable life style and to find their position in an extremely unstable and enormously complicated and divers world.

Oxfam claims that Education for Global Citizenship gives children and young people the opportunity to develop critical thinking about complex global issues in the safe space of the classroom, encourages children and young people to explore, develop and express their own values and opinions, whilst listening to and respecting other people's points of view, to care about the planet and to develop empathy with, and an active concern for, those with whom they share it. This is something that children of all ages need, for even very young children come face to face with the controversial issues of our time through the media and modern communications technology. (2006, p: 1).

Global citizenship education includes the following features:

- Comprehensive knowledge about world political systems

- Comprehensive knowledge about world economic systems

- Critical thinking skills that transcend boundaries

- Cross-cultural communication skills

- Provide active engagement

- Develop empathy: Global education must shift to help students personalize the world and internalize their connections to people living in worlds far away (Cartwright et al, 2009).

An important point in global citizenship education is to pay attention to the diversity and frequency of the issues raised at the current age and their continuity and overlap with each other on the one hand and their connection to global aspects and trends on the other hand that makes the need to organizing and designing the curriculum comprehensively and being careful in the formulation of its goals. Some countries have paid a particular attention to this issue including Curriculum Ontario Canada called ETFO (Evans et al 2010). 


\subsubsection{The Goals of Global Citizenship Education}

The main objective of education systems as one of the most effective educational institutions should be the education of the citizens, who are conscious, active, effective, participatory, deep-minded, flexible, having moral values as well as global and extensive attitude. The global citizenship education is seeking specific goals and objectives that are oriented toward adapting and controlling changes at the globalization age in order to achieve an appropriate life style in the $21^{\text {st }}$ century. Experts and professionals have considered different objectives for it.

Darison (1993) that has stated the objectives of global citizenship education as followings (quoted by Ghaedi, 2006; p: 200);

1) Recognition of other countries and awareness of their culture

2) Awareness of global issues and the role of the United Nations in their resolution

3) Identification of the issues related to human rights

4) Understanding the relationships between human and environment

Although, the important points related to global citizenship education have been suggested in the mentioned objectives, addressing some specific subjects limited to cognitive domain (knowledge and perception) is not only as ignoring the role and importance of emotional and dynamic domains, but it means to neglect great and global aspects of citizenship education and the role of global citizen as a citizen who is seeking contribution and is undertaking responsibilities. Thus, the objectives of global citizenship education should be explained by a comprehensive view and from a perspective beyond the recognition and awareness stage, focused on equipping the students with the required values, attitudes and skills and providing some opportunities for practical exercise in different fields in order to achieve a healthy life style for themselves and the others.

Cogan and Kubow believe that the aim in developing a global perspective is to expand and enrich students' perspectives, so that their views of the world are not ethnocentric, stereotypical or otherwise limited by a narrow or distorted point of view. If we neglect to nurture a global perspective students are likely to continue viewing the world narrowly through the lenses of their own interests, location and culture"(quoted by Evans and Reynolds, 2003; p 7-9).

According to Hanvey (1976) in An Attainable Global Perspective, five dimensions represent a combination of content themes, beliefs, and intellectual skills:

Perspective consciousness refers to an awareness of and appreciation for other images of the world, and recognition that others have views of the world that is profoundly different from one's own, State-of-the-plane awareness requires an in-depth understanding of the prevailing global issues, events, and conditions, Cross-cultural with an emphasis on understanding differences and similarities, Knowledge of global dynamics and, Awareness of human choices; a review of strategies for action on issues in local, national, and international settings(quoted by Miliziano, 2009, p.11).

Accordingly, holism, breadth of vision, cultural interactions, and exchange of views and conflict of viewpoints will enrich the ideas. Thus, education for living together in an interdependent world is not an optional extra, but an essential foundation. So pike and selby claim that "World mindedness is no longer a luxury but a necessity for survival in the new millennium"(2000, p: 12).

Therefore., the students will be converted to the citizens with necessary readiness for at living the current age. Thus, the global citizenship education should stand at the top of the education system programs and the curriculum goals shall focus on the global citizenship education.

Oxfam has presented principles and requirements as do's and don'ts of the global citizenship education in the following (Table 2).

\section{The Curriculum Goal}

Goals as the most important component of curriculum, serve a visionary function in it; a rallying point for all curriculum activities. Goals also have a global quality and a broad framework. They help in guiding and directing educational planning. They also establish the philosophy on which curriculum is based and express the values expected. Thus, aims constitute the first stage of curriculum planning"(Nyagah, 203; p: 40). A review on the extensive literature on citizenship shows that statesmen, experts and authorities in the area of curriculum are going to prepare the students for living in new conditions at the current age with regard to the global trends by making substantial changes in curriculums. Entering the 21st century, many countries have made substantial changes in their curriculum as one of the main components of education system by using the results of numerous 
investigations and studies conducted in the field of citizenship by many institutions, associations and research institutions such as International Association for the Evaluation of Educational Achievement (IEA).

Kerr(1999) has explained the Common goals were observed in the curriculum of sixteen countries participating in the citizenship studies (IEA). These objectives were consisted of the followings:

- Development of individual capabilities.

- Promotion of equal opportunities.

- Preparing the students for employment.

- The foundation for continuing the education and graduating studies.

- Growth and development of knowledge, skills and understanding.

- Promotion of citizenship (in the form of democracy or society) and the preservation of cultural heritage.

Many serious investigations and efforts also have been done in other countries to revise curriculums so that a large portion of curriculum goals have been allocated to discussion on the global issues. In the Curriculum of Ontario, Canada called ETFO Evans et al (2010) has stated that at the current era, for education of global citizenship, the concepts and components proposed in the global aspects which cause to enhance the capabilities required at the current age, should be taken into consideration as the focus of learning objectives in the curriculum goals.In the curriculum of Ontario, Canada where the components and aspects of global citizenship are at the center of the learning objective overlapping each other and having interaction.In the curriculum goals of Northern Ireland, one of the most important goals is the global citizenship education in order to prepare global citizens, while the continuity and exact and organized overlap between all goales is observable (NI Curriculumt, 2007).

In the comprehensive and known curriculum designed by Oxfam, three components including knowledge and understanding, skills and values and attitudes play key roles in upgrading a responsible global citizenship. He has designed his curriculum for global citizenship education separately for the groups in the age range of 5-19 years old, based on the mentioned components. Each of these components includes the following subsets as seen in the following table 3(Oxfam, 2006, p: 3). However, in spite of his holistic view, punctuality and high accuracy which indicate his awareness of the category of the global citizenship education, its position in the curriculum and the formulation of its goals, it seems that some other important and key components manage are absent including health issues, the effect of application of new technologies on human and environment, ethics and customs and etiquettes of using information and communications technology and employment issues as well as some other cases which should be particularly taken into consideration.

Swiniarski \& Breitborde have described ten principles of global education in line with global changes have provided an appropriate framework for the orientation of curriculum goals in order to educate global citizens. These principles are as followings:

- The global education is "a basic and essential education".

- The global education is "a lifelong learning".

- The global education includes "all individuals".

- The global education is "training for social action".

- The global education is "an economic education".

- The global education provides necessary conditions for "creative and critical thinking".

- The global education "requires IT engagements".

- The global education is "a multi-cultural education".

- The global education is "a moral education"(1999; p: 5).

The emphasis of such principles on the necessity of education from a global aspect as a continuous process and aiming to upgrade creative and critical thinking skills and required knowledge in the field of information and communication technology, economy, moral values, cultural interactions and to provide opportunities for practical exercise of the learned issues in order to get experience in a participatory manner, indicate its significant relationship with the principles, aspects and components of global citizenship education. 


\section{Discussion}

Citizenship is flexible, dynamic and fluid concept and has been changed from its meaning as city-state in the ancient Greece era and nation-state at the enlightenment age to a transnational and global concept in the age of globalization. As a result of developmental changes, the concept of citizenship as implying to the relationships between the society's political structure and the people, has been changed from its meaning as city-state in the ancient Greece era and nation-state at the enlightenment age to a transnational and global concept. Obviously, the ideal goal of any education system is to educate a good citizen for today and future life. A good citizen is a global citizen who is someone whose sense of identity, belonging, loyalty and commitment is not limited to local and national community. It is important for students as a good citizen to have the ability to consider alternative perspectives of how their lives relate to individuals worldwide, and in order to do so, they must have the knowledge to think critically about the events they hear. Students need to particular features and educating to deal with rapid, complex local, national and global issues, culture and religious conflicts and the other challenges ahead in the age of globalizations.

Global citizenship education is a strategic manner to prepare them in twenty-first century. The global citizenship education has not only originated from great philosophers' thoughts, but the mission of great prophets has been to build a better world through educating the human kind and to establish a unique and global nation. Turner stated: "I believe that world religions have been preliminary or initial versions of globalization" $(2006, \mathrm{p} 210)$. Therefore the accent should be placed on a basic education for everyone to build a society of productive, involved and responsible citizens and this issue will not be possible without an active, progressive, dynamic and productive approach in setting goals. of the curriculum.

\section{Conclusion}

Continuous growth and expansion of information and communications technologies as one of the most important developments of the last century have resulted in great achievements for the mankind. Globalization in its process implication as the natural trend of the history that is a result of information revolution on the one hand and it has been accelerated by development process has caused extensive changes in different economic, political and social fields. In spite of negative outcomes and consequences of globalization, it may be considered not as a threat, but as an opportunity to actualize the capabilities, to improve capacities and in general, an opportunity for full development of the human. To benefit from globalization, individuals and societies must develop broad knowledge bases and have specialized skills, and become more nimble and adaptable to change. In global citizenship education, setting goals of the curriculum are based on a dynamic and fluid concept of citizenship. In other words the objectives of the curriculum focus on educating citizens who are prepared in the presence and active participation in the local, national and global levels. Hence, the curriculum as a dynamic process must continually revise the goals. They should be organized so that they can come to an answer for the fluidity of the citizenship concept. The curriculum goals proposed for global citizenship education must emphasize on:

- Developing citizens of the world in relation to culture, language and learning to live together.

- Fostering students' recognition and development of universal human values.

- Equipping students with the skills to learn and acquire knowledge, individually or collaboratively, and to apply these skills and knowledge accordingly across a broad range of areas.

The most important point in the global citizenship education is to prepare the ground for its realization. It is strongly based on democracy and information technology. Undoubtedly, the availability of a demarcate society is a prerequisite for the realization of global citizenship education, because the people's rights are recognized in such societies and different sounds can be heard regardless of any difference. At the same time, an opportunity will be opened up for them to participate and affect the major decisions taken as widespread. Familiarity of the citizens with democratic processes paves the way for citizenship education on the one hand and the democracy itself is considered as one of the important components of citizenship education, so that UNESCO (2005) argued about an interest in civil rights and revitalization of citizenship education in 1990 as the third wave of democracy. Another prerequisite facilitating the realization of global citizenship is to prepare the ground for the establishment of a desirable relationship between the school and a larger community. Despite the key role of training in citizenship education, if there is no opportunity to exercise practically what have been learned, the citizenship education would not be realized. Linking with society offers students the opportunity to experience the global value of interdependence, gain essential skills for public work, and help build a civic global network; In fact, one of the essential requirements of democracy process is to provide an opportunity for active participation that will result in accountability in the citizens. At the end, global citizenship education shall be considered as a permanent and lifelong process and be rather resumed by the related institutions after graduation. 
Therefore, today citizen requires a comprehensive education for living in the global conditions. Accordingly, global citizenship education issue should be considered at the top of the educational system programs and the curriculums goals. the curriculum goals proposed for global citizenship education may be displayed in the table 4 , emphasizing its essential components.

Table 1. Civil Society and Global Governance (Levels of governance and citizenship)

\begin{tabular}{|c|c|c|c|}
\hline $\begin{array}{l}\text { System of } \\
\text { Governance }\end{array}$ & $\begin{array}{l}\text { Socio-political } \\
\text { personhood }\end{array}$ & $\begin{array}{l}\text { Key rights and } \\
\text { obligations }\end{array}$ & $\begin{array}{l}\text { Example of relevant } \\
\text { organized institution }\end{array}$ \\
\hline City-state & Denizen & $\begin{array}{l}\text { Legal rights and } \\
\text { obligations }\end{array}$ & Jury system \\
\hline Nation-state & Citizen & $\begin{array}{l}\text { Political rights and } \\
\text { obligations }\end{array}$ & Parliament \\
\hline Welfare State & Social citizen & $\begin{array}{l}\text { Social rights and } \\
\text { obligations }\end{array}$ & Social Welfare agencies \\
\hline Global governance & Global citizen & $\begin{array}{l}\text { Global rights and } \\
\text { obligations }\end{array}$ & $\begin{array}{l}\text { Global institutions for } \\
\text { example, UN System }\end{array}$ \\
\hline
\end{tabular}

(Muetzelfeldt \& Smith, 2006, p: 61)

Table 2. Principles and Requirements of Global Citizenship Education

\begin{tabular}{|c|c|}
\hline Education for Global Citizenship is: & Education for Global Citizenship is not: \\
\hline 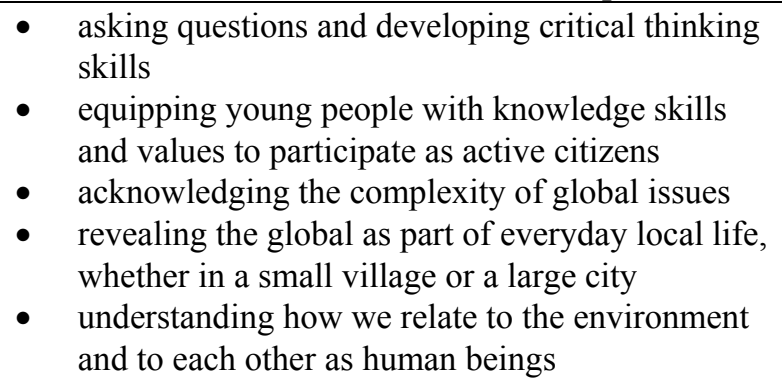 & $\begin{array}{l}\text { - } \quad \text { too difficult for young children to understand } \\
\text { - } \quad \text { mostly or all about other places and peoples } \\
\text { - } \quad \text { providing simple solutions to complex issues } \\
\text { - } \quad \text { an extra subject to cram into a crowded curriculum } \\
\text { - } \quad \text { about raising money for charity }\end{array}$ \\
\hline
\end{tabular}

(Oxfam, 2006)

Table 3. Three components including knowledge and understanding, skills and values and attitudes

\begin{tabular}{|c|c|c|}
\hline & Responsible global citizenship & \\
\hline $\begin{array}{ll} & \text { Knowledge and understanding } \\
\text { - } & \text { social justice and equity } \\
\text { - } & \text { diversity } \\
\text { - } & \text { globalization and interdependence } \\
\text { - } & \text { sustainable development } \\
\text { peace and conflict }\end{array}$ & 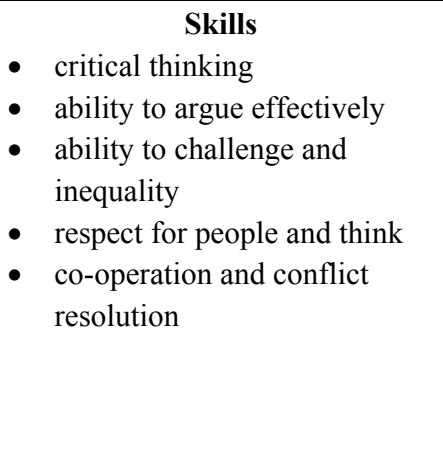 & $\begin{array}{l}\text { Values and attitudes } \\
\text { - } \quad \text { sense of identity and } \\
\text { self-esteem } \\
\text { - } \text { empathy } \\
\text { - } \text { commitment to social justice } \\
\text { - } \quad \text { value and respect for diversity } \\
\text { - } \quad \text { concern for the environment } \\
\text { and commitment to sustainable } \\
\text { development } \\
\text { - } \text { believe that people can make a } \\
\text { different }\end{array}$ \\
\hline
\end{tabular}

(Oxfam, 2006) 
Table 4. The Proposed Curriculum Goals in Global Citizenship Education

\begin{tabular}{ll}
\hline \multirow{3}{*}{ Promotion of Knowledge and Understanding } & $\begin{array}{l}\text { Sufficient knowledge and awareness of citizenship role } \\
\text { (contribution, responsibility, identity and social } \\
\text { belonging) }\end{array}$ \\
Literacy (basic skills, computer literacy, political \\
literacy \\
Understanding of existing differences (cultural, racial, \\
gender, religious and lingual) \\
Awareness of health issues
\end{tabular}

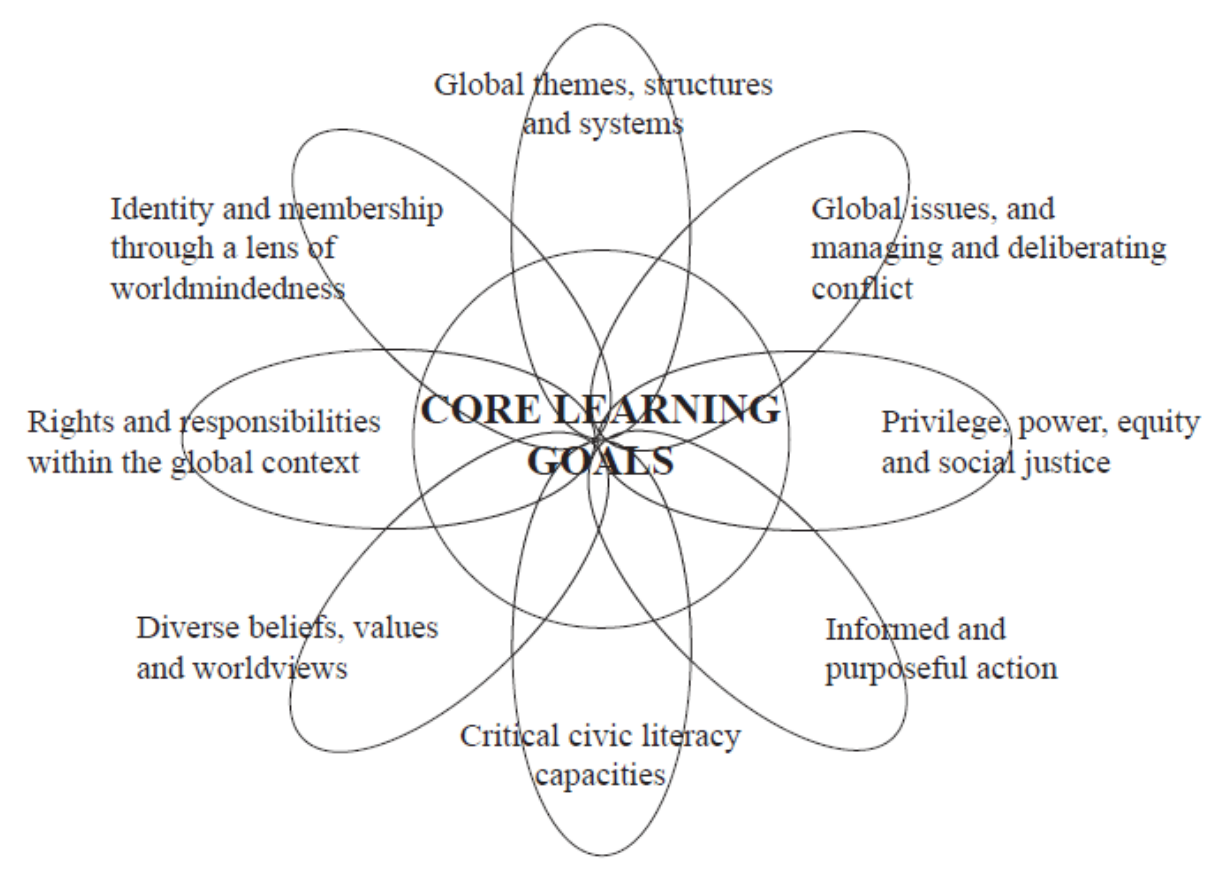

Figure 1. s Learning Goals Associated with Global Citizenship Education - Ontario

(Evans et al., 2010) 


\section{Acknowledgements}

We are acknowledged and thank Dr. Arbabisarjou, Azizollah, Ph.D, Assistant Professor and Faculty member at Zahedan University of Medical Sciences and Dr, Shavaran, Sayed Hamidreza, Ph.D, in Educational Management for warmly cooperation, communication and consulting .

\section{References}

Banks, J. A. (2004). Teaching for Social Justice, Diversity, and Citizenship in a Global World, The Educational Forum, 68.

Banks, J. A. (2008). Diversity, Group Identity, and Citizenship Education in a Global Age. http://dx.doi.org/10.3102/0013189X08317501

Blevins, Dawn M. (2011). New Directions in Citizenship Education Globalization, State Standards and an Ethical/Critical Social Studies Curriculum, Ph.D Dissertation, Ohio State University.

Bliss, S. (2005). Growing Global Education and Globalizations in AUSTRALIA, Presented: Pacific Circle Consortium International Conference. University of Western Sydney.

Brigham, M. (2011). Creating citizen and assessing outcomes. Journal of Global Citizenship \& Equity Education, 1.

Cartwright, C. T., Kerrigan, P. Pusch, M., Brown, B., \& Yamashita, M. (2009). Global Citizenship; Challenges and Opportunities for U.S. Higher Education, Presentation for AAC\&U Seattle, WA.

Chen, S. (2008). Developing Global Citizenship: the Effect of Studying Abroad. Osaka University, Japan.

Doering, H. (2008). Communities and citizenship: paths for engagement? School of Social Science, Cardiff University.

Evans, M., \& Reynolds, C. (2003). Introduction: Educating for Global Citizenship in a Changing World. Project Coordinators.

Evans, M., Broad, K., \& Rodrigue, A. (2010). Educating for GlobaCitizenship. An ETFO Curriculum Development Inquiry Initiative, Ontario, Funded in part by the Government of Ontario.

Evans, M., Ingram, L. A., Macdonald, A., \& Weber, N. (2009). Mapping the "global dimension" of citizenship education in Canada: The complex interplay of theory, practice and context, University of Toronto Citizenship. Teaching and Learning, 5(2).

Ghaedi, Y. (2006). Educating future citizenship, Revew Quarterly, Journal of Educational Innovations, 5(17).

Global dimension DEAs. (2007). Promoting Education For A Just And Sustainable Development. The Global Dimension in the Curriculum - Northern Ireland. Retrieved from www.globaldimension.org.uk

Grodzinsky, F. (1999). The Practitioner from within: revisiting the virtues. Sacred Heart University USA.

Hanson, L. (2010). Global Citizenship, Global Health, and the Internationalization of Curriculum A Study of Transformative Potential, University of Saskatchewan, Journal of Studies in International Education, 14(1). http://dx.doi.org/10.1177/1028315308323207

Hartley, D. (2001). The Green Citizenship, Blackwell. Retrieved from http://eprint.ise.ac.uk/

Isin, E. F. (2009). Citizenship in flux: The figure of the activist citizen. Politics and International Studies(POLIS).

Jarrar, A. J. (2012). Global citizenship education in Jordanian Universities SciVerse ScienceDIRECT. http://dx.doi.org/10.1016/j.sbspro.2012.06.924

Jefferess, D. (2002). Global citizenship and the cultural politics of benevolence. University of British Columbia - Okanagan, Canada.

Jorgenson, S., \& Shultz, L. (2012). Global Citizenship Education (GCE) in Post-Secondary Institutions: What is Protected and what is Hidden under the Umbrella of GCE? Journal of Global Citizenship \& Equity Education, 2(1). (Special Edition).

keeping, J., \& Shapiro, D. (2008). Global Citizenship What is it, and what are our ethical obligations as global citizens? Feature Report on Citizenship. Retrieved from Photomo/Dreamstime.com

Kerr, D. (1999). Citizenship education: an international comparison. INCA

Mayo, M., Gaventa, J., \& Rooke.A. (2009). Learning global citizenship?: Exploring connections between the local and the global, Published by Sage. http://dx.doi.org/10.1177/1746197909103935 
Miliziano, K. R. (2009). Teaching social studies in an age of globalization: A case study of secondary social studies teachers' participation in the UNA-USA's Global Classrooms curriculum program, $\mathrm{Ph} . \mathrm{D}$ dissertation. Department of Secondary Education College of Education, University of South Florida.

Muetzelfeldt, M., \& Smith, G. (2002). Civil Society and Global Governance: The Possibilities for Global Citizenship. Citizenship Studies, 6(1). carfax publishing. Taylor \& Fancies Group.

Munck, R. (2010). Civic Engagement and Global Citizenship in a University Context: Core business or desirable add-on? Published by Sage. http://dx.doi.org/10.1177/1474022209350102

Naveheebrahim, A., \& Masoudi, S. (2011). Citizenship behavior among the Iranian elementary school students. International Conference on Social Science and Humanity, 5.

Noddings, N. (2005). Educating citizenship for global awareness. Published in teachers college press, New York, USA.

Nyaghah, G. (2003). Curriculum Stydies. African Virtual University Scribd. Retrieved from http://creativecommons.org/licences/by/205

Oenen, G. V. (2010). Three cultural turns: how multiculturalism, interactivity and interpassivity affect citizenship. London: Routledge. http://dx.doi.org/10.1080/13621021003731856

Oxfam, C. H. (2006). Education for Global Citizenship. A Guide for Schools.

Pike, G., \& Selby, D. (2000). In the global classroom, 2. Toronto: Pippin Publishing.

Purta, T., Sewill, J., Amadeo, J., \& Ann, J. (1999). Civic Education across countries: Twenty-Four National case studies from the IE. Civic Education Project.

Schweisfurth, M. (2006). Education for global citizenship: teacher agency and curricular structurenin Ontario schools. University of Birmingham, UK Routledge, 58(1). http://dx.doi.org/10.1080/00131910500352648

Sears, A. M., \& Hughes, A. S. (1996). Citizenship education and current educational reform. Canadian journal of education: pp 123-142.

Simon, A. (2006). Citizenship and Multiculturalism: A Critical Assessment. Newman University College Birmingham.

Stevens, C. R., \& Campbell, P. J. (2006). Collaborating to connect global citizenship, information literacy, and lifelong learning in the global studies classroom, Reference Services Review, 34(4). Emerald Group Publishing. http://dx.doi.org/10.1108/00907320610716431

Stewart, L. (2008). Global Citizenship and Wilfrid Laurier University. Laurier Students' Public Interest Research Group, Ontario Canada.

Sullivan, M. O., \& Pashb, K. (ed). (2008). Citizenship Education in the era Globalization Canadian Perspectives, Ontario Institute for Studies in Education/University of Toronto, Canada, SENSE PUBLISHERS, ROTTERDAM /TAIPEI. Retrieved from http://www.sensepublishers.com Citizenship

Swiniarski, L., Breitbordem, \& Murphy. (1999). Educating the global village: An inclusive view of the child in the world. Columbus, Ohio: prentice Hall -Merrill.

The Dragon Foundation. (2012). Understanding of Conflict in a Global Perspective. Global Citizenship PROGRAM.

Turner, B. S. (2006). Translated by karbaschi, M., Purang, H., \& Hajiheidari, H. Cosmopolitan Virtue: On Religion In A "Global Age".

UNESCO. (2005). What is Human Right Education. Retrieved from www.Unesdoc.Unesco.org 